\title{
VAKSINASI IKAN TILAPIA (Oreochromis niloticus) MENGGUNAKAN VAKSIN MONOVALEN DAN BIVALEN UNTUK PENCEGAHAN PENYAKIT MOTILE AEROMONAS SEPTICEMIA DAN STREPTOCOCCOSIS
}

\author{
Desy Sugiani*), Sukenda**), Enang Harris**), dan Angela Mariana Lusiastuti*) \\ *) Balai Penelitian dan Pengembangan Budidaya Air Tawar \\ Jl. Sempur No. 1, Bogor 16154 \\ E-mail: desysugiani@yahoo.co.id \\ **) Institut Pertanian Bogor \\ Jl. Rasamala, Kampus IPB Darmaga, Bogor 16680
}

(Naskah diterima: 16 Maret 2012; Disetujui publikasi: 9 April 2013)

\begin{abstract}
ABSTRAK
Peningkatan respon antibodi pascavaksinasi dengan antigen tunggal dan campuran dari bakterin Aeromonas hydrophila and Streptococcus agalactiae diharapkan dapat meningkatkan daya tahan ikan Tilapia (Oreochromis niloticus) terhadap penyakit Motile Aeromonas Septicemia/MAS dan Streptococcosis. Sediaan vaksin disiapkan dengan metode pembuatan dan formula yang berbeda, proses inaktifasi dilakukan dengan menambahkan 3\% Neutral Buffer Formalin (NBF 10\%) pada biakan bakteri dalam media tumbuh BHI dan TSB. Vaksinasi diberikan melalui injeksi intraperitoneal dengan sediaan vaksin monovalen A. hydrophila, monovalen S. agalactiae, dan bivalen A. hydrophila + S. agalactiae (Sel utuh, produk ektraselular/ECP, crude supernatan, campuran sel utuh + ECP, dan broth). Uji tantang dilakukan menggunakan dosis $\mathrm{LD}_{50}$ infeksi tunggal maupun ko-infeksi dari bakteri $A$. hydrophila dan S. agalactiae. Efektivitas dan keampuhan vaksin tersebut dihitung berdasarkan nilai RPS (Relative Percent Survival) dan hasil respon hematologi. Titer antibodi dapat terdeteksi setelah satu minggu pemeliharaan pascavaksinasi. Nilai titer antar perlakuan vaksin bivalen berbeda nyata $(P<0.05)$ dengan vaksin monovalen dan kontrol. Nilai RPS vaksin bivalen (campuran sel utuh +ECP) mencapai 100 untuk uji tantang dengan $A$. hydrophila dan 56.7 pada uji tantang ko-infeksi. Vaksin monovalen A. hydrophila maupun S. agalactiae hanya mampu memproteksi terhadap bakteri homolog, tidak terjadi proteksi silang di antara keduanya.
\end{abstract}

KATA KUNCI: A. hydrophila, S. agalactiae, vaksin monovalen, vaksin bivalen, antibodi, RPS

ABSTRACT: Vaccination of Tilapia (O. niloticus) using monovalent and bivalent vaccines for Motile Aeromonas Septicemia and Streptococcosis disease. By: Desy Sugiani, Sukenda, Enang Harris, and Angela Mariana Lusiastuti

Increased antibody responses post vaccination with single and mixed bacterin of $A$. hydrophila and S. agalactiae were expected to increased protection of Tilapia ( $O$. niloticus) to Motile Aeromonas Septicemia / MAS and Streptococcosis disease. Vaccine were prepared by different method and formulas, inactivation process was done by adding 3\% Neutral Buffer Formaldehyde (NBF 10\%) in bacterial culture medium (BHI and TSB). Vaccinations were administered by intraperitoneal injection with 
monovalent A. hydrophila, monovalent S. agalactiae, and bivalent A. hydrophila $+S$. agalactiae (whole cells, extracellular product / ECP, crude supernatant, mixed whole cells $+E C P$, and broth). Challenge test was performed using $L D_{50}$ dose with single infection and co-infection of bacterium A. hydrophila and S. agalactiae. Effectiveness and efficacy of the vaccine was calculated based on the RPS (Relative Percent Survival) and the results of hematological response. Antibody titre could be detected at one week post vaccination. Bivalent vaccine titre between treatments were significantly different $(P<0.05)$ with monovalent vaccine and control. RPS values for bivalent vaccine (mixed of whole cells + ECP) was 100 after challenge test with A. hydrophila and 56.7 after challenge test with co-infection. Monovalent vaccine of A. hydrophila and S. agalactiae just protected against bacterial homologues there was, no cross-protection occurred between them.

\section{KEYWORDS: A. hydrophila, S. agalactiae, monovalent vaccine, bivalent vaccine,} antibody response, RPS

\section{PENDAHULUAN}

Perkembangan penanggulangan penyakit dalam budidaya ikan lebih cenderung memilih cara pencegahan dengan strategi vaksinasi yang dapat secara spesifik melindungi baik dari tipe patogen maupun spesies ikan. Vaksinasi yang dikombinasikan dengan praktek sistem manajemen budidaya yang baik dapat menjadi substansi pencegahan penyakit sehingga hasil produksi lebih dapat diprediksi. Penanggulangan penyakit MAS dan Streptoccoccosis akibat infeksi $A$. hydrophila dan $S$. agalactiae menggunakan vaksin monovalen telah banyak dilakukan. Penggunaan vaksin bivalen untuk sekaligus melindungi ikan Tilapia dari serangan infeksi kedua jenis penyakit tersebut belum dilakukan.

Lusiastuti et al. (2010) dan Hardi et al. (2010) mengemukakan bahwa pada ikan Tilapia yang diberi vaksin bakteri $S$. agalactiae isolat $\mathrm{N}_{14} \mathrm{G}$ secara injeksi menggunakan sediaan berupa produk ekstraselular (ECP) dan sel utuh maupun kombinasi keduanya diperoleh RPS $>90$. Hasil tersebut sesuai dengan riset penggunaan vaksin S. agalactiae untuk penanggulangan Streptococcosis yang telah dikembangkan dari produk ekstraselular dan sel utuh dengan inaktifasi menggunakan formalin (Pasnik et al., 2005).

Vaksin A. hydrophila sediaan sel utuh yang diinaktifasi menggunakan formalin dan diaplikasikan melalui oral pada ikan Tilapia $(O$. niloticus) menghasilkan relative level of protection (RLF) sebesar 86,8 (Ismail et al., 2010). Sugiani et al. (2010) melakukan penelitian vaksinasi ikan lele (Clarias gariepinus) menggunakan sediaan vaksin sel utuh $A$. hydrophila isolat AHL0905-2 yang diinaktifasi menggunakan formalin $(0,3 \% \mathrm{v} / \mathrm{v})$ dan diaplikasikan melalui perendaman, perlakuan vaksin menghasilkan Relative Percent Survival (RPS) sebesar 98,75 dengan level titer antibodi log 2 pada nilai 4 setelah divaksinasi selama 21 hari.

Strategi vaksinasi memerlukan pertimbangan terhadap penyakit spesifik yang akan dipapar, jenis vaksin, metode vaksinasi, pemilihan waktu vaksinasi dan perlakuan vaksinasi ulang (booster). Perumusan vaksin yang ideal dapat diambil dalam bentuk vaksin polivalen untuk melindungi secara serempak terhadap beberapa penyakit. Vaksin polivalen harus mampu melindungi dari semua serotipe dari tiap patogen penyebab penyakit tertentu. Di samping itu, perlu diperhatikan kompetisi antigen spesifik yang mungkin terjadi terutama ketika vaksin diaplikasikan melalui penyuntikan (Toranzo et al., 2009).

Beberapa penelitian mengenai vaksin bivalen dan polivalen pada ikan menunjukkan hasil yang bervariasi, dikarenakan setiap strain bakteri memiliki kemampuan antigenik yang berbeda. Osman et al. (2009) melakukan penelitian vaksinasi pada Tilapia terhadap infeksi Aeromonas dan Pseudomonas menggunakan vaksin monovalen dengan RPS yang bervariasi antara 73-89. Vaksin bivalen memberikan RPS sebesar 74 , sedangkan vaksin polivalen yang merupakan gabungan vaksin bakterin Aeromonas spp. ( $A$. hydrophila, A. Sobria, dan A. caviae) dan Pseudomonas fluorescens menunjukkan RPS 81. Silva et al. (2009) melakukan penelitian hematologi dan respon immunologi ikan Tilapia setelah vaksinasi menggunakan vaksin polivalen bakterin A. hydrophila, P. aeroginosa, 
dan Enterococcus durans, diketahui bahwa titer antibodi tertinggi diperoleh pada hari ke21 setelah vaksinasi. Vaksin campuran antara sel utuh antigen A. hydrophila + Edwardsiella tarda $+P$. fluorescens merupakan patogen dari kelompok bakteri Gram negatif hasil isolasi pada Indian major carps yang dapat merangsang respon antibodi pada rohu, Labeo rohita (Ham.) (Swain et al., 2007).

Pembentukan vaksin bivalen atau polivalen akan dipengaruhi oleh banyak proses imunologi seperti reaksi silang antigen (cross-reaction antigenic), kompetisi antigen, waktu pematangan, dan penghilangan sifat antigenik yang akan mempengaruhi efektivitas, kemampuan menghasilkan respon imun dan level antibodi.

\section{BAHAN DAN METODE}

Ikan uji. Ikan Tilapia (O. niloticus) berukuran $30 \pm 0,5 \mathrm{~g}$.

Bakteri. Isolat bakteri menggunakan isolat koleksi Kementrian Kelautan dan Perikanan, Balai Penelitian dan Pengembangan Budidaya Air Tawar Bogor, A. hydrophila menggunakan isolat AHL0905-2 dan $S$. agalactiae menggunakan isolat $\mathrm{N}_{14} \mathrm{G}$.

Vaksin. Ada 5 sediaan vaksin yang akan di uji pada penelitian ini yaitu vaksin sel utuh, produk ektraselular/ECP, crude supernatan, campuran sel utuh + ECP, dan broth.

Preparasi sediaan vaksin. Preparasi vaksin bivalen menggunakan cara kultur dengan modifikasi metode kultur terpisah menurut Silva et al. (2009). Proses inaktifasi vaksin dilakukan dengan menambahkan bufer formalin dalam sediaan kultur bakteri. Vaksin yang dibuat pada penelitian ini adalah vaksin bivalen yang berisi campuran dari sel utuh, $\mathrm{ECP}$, sel utuh + ECP, crude supernatan, dan sediaan broth dari bakteri $A$. hydrophila dan $S$. agalactiae. Vaksin bivalen dibuat dengan mencampurkan masing-masing sediaan vaksin dengan perbandingan 1:1 (v/v). Prosedur pembuatan vaksin yang dilakukan adalah sebagai berikut:

\section{Sediaan Vaksin Sel Utuh}

Vaksin sel utuh $A$. hydrophila dibuat dengan modifikasi metode Ismail et al. (2010) dan Rodrigues et al. (2006). Bakteri A. hydrophila diinokulasi dalam media BHI, diinkubasi dalam inkubator dengan shaker selama 24 jam pada suhu $28^{\circ} \mathrm{C}$. Kultur bakteri diinaktifasi dengan menambahkan $10 \%$ bufer formalin hingga konsentrasi akhir formalin menjadi 0,3\% (v/v) disimpan selama 24 jam pada suhu $28^{\circ} \mathrm{C}$. Sel utuh bakteri in-aktif diperoleh dengan mensentrifus pada $3.000 \mathrm{~g}$ selama 30 menit dan pelet (endapan) sel diresuspensi dengan PBS $(\mathrm{pH} 7,2)$. Hasil resuspensi sediaan sel utuh disimpan pada suhu $4^{\circ} \mathrm{C}$.

Vaksin sel utuh $S$. agalactiae dibuat dengan modifikasi metode Shoemaker et al. (2010) dan Evans et al. (2004). Bakteri S. agalactiae diinokulasi dalam media TSB, diinkubasi di inkubator dengan shaker selama 72 jam pada suhu $28^{\circ} \mathrm{C}$. Kultur bakteri diinaktifasi dengan menambahkan $10 \%$ bufer formalin hingga konsentrasi akhir formalin menjadi $0,3 \%(\mathrm{v} / \mathrm{v})$ disimpan selama 24 jam pada suhu $28^{\circ} \mathrm{C}$. Hasil inaktifasi dengan formalin disentrifus pada $3.000 \mathrm{~g}$ selama 30 menit, pelet sel bakteri dan supernatan dipisahkan. kemudian pelet diresuspensi dalam larutan salin 0,845\% steril dengan rasio 1:10 (v/v). Hasil resuspensi sediaan sel utuh disimpan pada suhu $4^{\circ} \mathrm{C}$.

\section{Sediaan Vaksin ECP}

Vaksin ECP A. hydrophila dibuat dari extracellular product (ECP) bakteri $A$. hydrophila modifikasi metode yang dilakukan $\mathrm{Ni}$ et al. (2010) dengan beberapa modifikasi. Bakteri $A$. hydrophila diinokulasi dalam media BHI diinkubasi selama 24 jam pada suhu $28^{\circ} \mathrm{C}$ diinkubator dengan shaker. Hasil kultur ditambahkan $10 \%$ bufer formalin hingga konsentrasi akhir formalin $0,3 \%(\mathrm{v} / \mathrm{v})$ kemudian disimpan selama 24 jam pada suhu $28^{\circ} \mathrm{C}$ (proses inaktifasi). Hasil inaktifasi disentrifus pada 3.000 g selama 30 menit. Pelet (endapan) sel bakteri dipisahkan dari supernatan. Supernatan yang berisi ECP diaduk mengunakan shaker, kemudian disaring memakai filter steril $(0,45$ ìm) untuk menghilangkan residu bakteri. Hasil saringan disimpan dalam mesin pendingin pada suhu $20^{\circ} \mathrm{C}$.

Vaksin ECP S. agalactiae dibuat dengan metode seperti yang dilakukan oleh Hardi (2011), Klesius et al. (1999) dan Evans et al. (2004) dengan beberapa modifikasi. Bakteri S. agalactiae diinokulasi pada media TSB, diinkubasi pada suhu $28^{\circ} \mathrm{C}$ selama $72 \mathrm{jam}$. Hasil kultur ditambahkan $10 \%$ bufer formalin hingga konsentrasi akhir formalin 0,3\% (v/v) kemudian disimpan selama 24 jam pada suhu $28^{\circ} \mathrm{C}$ (proses inaktifasi). Hasil inaktifasi kemudian 
disentrifus pada $3.000 \mathrm{~g}$ selama 30 menit. Pelet (endapan) sel bakteri dipisahkan dari supernatan. Supernatan yang berisi ECP diaduk mengunakan shaker, kemudian disaring memakai filter steril $(0,22$ ìm) untuk menghilangkan residu bakteri. Hasil saringan disimpan dalam mesin pendingin pada suhu $20^{\circ} \mathrm{C}$.

\section{Sediaan Vaksin Crude Supernatan}

Vaksin crude supernatan A. hydrophila dibuat dari bakteri $A$. hydrophila yang diinokulasi dalam media BHI, diinkubasi dalam inkubator dengan shaker selama 24 jam pada suhu $28^{\circ} \mathrm{C}$. Kultur bakteri diinaktifasi dengan menambahkan $10 \%$ bufer formalin hingga konsentrasi akhir formalin menjadi $0,3 \%(\mathrm{v} / \mathrm{v})$ disimpan selama 24 jam pada suhu $28^{\circ} \mathrm{C}$. Sel bakteri in-aktif diperoleh dengan mensentrifus pada $3.000 \mathrm{~g}$ selama 30 menit, suspensi bakteri dipisahkan dari pelet (endapan). Suspensi sediaan crude supernatan disimpan pada suhu $4^{\circ} \mathrm{C}$.

Vaksin crude supernatan bakteri $S$. agalactiae dibuat dari bakteri S. agalactiae yang diinokulasi dalam media TSB, diinkubasi di inkubator dengan shaker selama 72 jam pada suhu $28^{\circ} \mathrm{C}$. Kultur bakteri diinaktifasi dengan menambahkan $10 \%$ bufer formalin hingga konsentrasi akhir formalin menjadi $0,3 \%(\mathrm{v} / \mathrm{v})$ disimpan selama 24 jam pada suhu $28^{\circ} \mathrm{C}$. Hasil killing dengan formalin disentrifus pada 3.000 g selama 30 menit, pelet dan suspensi bakteri dipisahkan. Suspensi sediaan crude supernatan disimpan pada suhu $4^{\circ} \mathrm{C}$.

\section{Sediaan Vaksin Broth}

Vaksin broth A. hydrophila dibuat dari bakteri $A$. hydrophila yang diinokulasi dalam media $\mathrm{BHI}$, diinkubasi dalam inkubator dengan shaker selama 24 jam pada suhu $28^{\circ} \mathrm{C}$. Kultur bakteri diinaktifasi dengan menambahkan $10 \%$ bufer formalin hingga konsentrasi akhir formalin menjadi 0,3\% (v/v) disimpan selama 24 jam pada suhu $28^{\circ} \mathrm{C}$. Sediaan broth disimpan pada suhu $4^{\circ} \mathrm{C}$.

Vaksin broth bakteri $S$. agalactiae dibuat dari bakteri $S$. agalactiae yang diinokulasi dalam media TSB, diinkubasi dalam inkubator dengan shaker selama 72 jam pada suhu $28^{\circ} \mathrm{C}$. Kultur bakteri diinaktifasi dengan menambahkan $10 \%$ bufer formalin hingga konsentrasi akhir formalin menjadi $0,3 \%(\mathrm{v} / \mathrm{v})$ disimpan selama 24 jam pada suhu $28^{\circ} \mathrm{C}$. Sediaan broth disimpan pada suhu $4^{\circ} \mathrm{C}$.

Uji kualitas vaksin bivalen. Uji keamanan vaksin (Innocuity test) menggunakan metode Anderson et al. (1970) dengan menginokulasi sel bakteri dari sediaan vaksin pada ikan Tilapia (O. niloticus) secara intra peritoneal (IP) dan sebagai kontrol ikan diinjeksi dengan salin fisiologis. Setelah 15 hari dilakukan reisolasi bakteri S. agalactiae dan $A$. hydrophila dari ikan perlakuan untuk melihat koloni bakteri yang sama. Vaksin yang dikatakan aman jika hasil dari reisolasi tidak diperoleh bakteri aktif yang sama dengan isolat vaksin. Uji sterilitas vaksin (Sterility test) seperti yang dilakukan Aly (1981) dengan melakukan kultivasi sediaan vaksin dalam BHIA

Tabel 1. Perlakuan vaksin dan komponen uji tantang pada ikan tilapia (Oreochromis niloticus)

Table 1. Vaccine treatment and challengeon tilapia (Oreochromis niloticus) fish

\begin{tabular}{|c|c|c|}
\hline $\begin{array}{l}\text { Perlakuan } \\
\text { Treatment }\end{array}$ & $\begin{array}{l}\text { Komponen vaksin } \\
\text { Vaccine component }\end{array}$ & $\begin{array}{c}\text { Komponen uji tantang } \\
\text { Challenge }\end{array}$ \\
\hline 1 & Monovalen A. hydrophila & A. hydrophila, S. agalact iae, dan ko-infe ksi \\
\hline 2 & Monovalen S. agalactiae & A. hydrophila, S. agalactiae, dan ko-infe ksi \\
\hline 3 & Bivalen Sel utuh & A. hydrophila, S. agalactiae, dan ko-infe ksi \\
\hline 4 & Bivalen ECP & A. hydrophila, S. agalactiae, dan ko-infe ksi \\
\hline 5 & Bivalen Sel utuh+ECP & A. hydrophila, S. agalactiae, dan ko-infeksi \\
\hline 6 & Bivalen Crude Supernatan & A. hydrophila, S. agalactiae, dan ko-infe ksi \\
\hline 7 & Bivalen Brot $h$ & A. hydrophila, S. agalactiae, dan ko-infe ksi \\
\hline 8 & Kontrol TSB & Ko-infeksi \\
\hline 9 & Kontrol BHI & Ko-infeksi \\
\hline 10 & Kontrol Saline 0,845\% & Ko-infeksi \\
\hline 11 & Kontrol tanpa injeksi & Ko-infeksi \\
\hline
\end{tabular}


yang diinkubasi pada suhu $25^{\circ} \mathrm{C}$ selama 24 jam untuk memastikan tidak ada bakteri yang tumbuh dari jenis $A$. hydrophila maupun $S$. agalactiae.

Perlakuan vaksin. Ikan Tilapia diberi perlakuan vaksin gabungan hasil kultur terpisah bakteri $A$. hydrophila dan $S$. agalactiae (Tabel 1) dengan perbandingan volume sediaan vaksin 1:1 ( $/ \mathrm{v})$, setiap ikan disuntik vaksin 0,1 mL/ikan (Silva et al., 2009).

Titer antibodi. Pengamatan terhadap titer antibodi menggunakan aglutinasi langsung (direct aglutination) terhadap antigen- antibodi perlakuan. Nilai titer dimasukkan dalam hitungan $\log 2$.

Uji tantang. Uji tantang dilakukan terhadap 5 kelompok perlakuan vaksin bivalen, 2 kelompok perlakuan vaksin monovalen, dan 4 kelompok kontrol dengan melakukan uji tantang pada minggu ke-3 (Li et al., 2006). Uji tantang ini dimaksudkan untuk melihat proteksi vaksin dengan mengamati kematian ikan agar diperoleh perhitungan Relative Percent Survival (RPS). Bakteri untuk uji tantang di kultur dalam BHIB pada suhu $25^{\circ} \mathrm{C}$ selama 24 jam. Dosis bakteri menggunakan hasil LD $_{50}$ dari kedua jenis bakteri uji. Ikan diinjeksi secara intra peritoneal sebanyak 0,1 $\mathrm{ml}$ /ekor. Ikan yang mati diamati dan dicatat gejala klinis yang muncul, pengamatan dilakukan selama 14 hari. Tingkat sintasan (SR) setelah uji tantang dicatat dan dihitung Relative Percent Survival (RPS) untuk melihat efektivitas vaksinasi dengan menggunakan rumus Ellis (1988):

$$
\text { RPS }=\left(1-\frac{\text { per cent vaccinate mortality }}{\text { per cent control mortality }}\right) \times 100
$$

\section{HASIL DAN BAHASAN}

\section{Kematian ikan kumulatif harian}

Sediaan vaksin monovalen dan bivalen diuji kualitasnya dengan melihat tingkat keamanan dan sterilitas dari vaksin. Hasil yang diperoleh bahwa sediaan vaksin monovalen dan bivalen (sel utuh, produk ekstraselular/ $\mathrm{ECP}$, crude supernatan, gabungan sel utuh dan ECP, broth) yang diinaktifasi menggunakan 3\% bufer formalin aman dan steril untuk digunakan. Hasil re-isolasi terhadap beberapa ikan pascavaksinasi tidak diperoleh adanya pertumbuhan bakteri yang sama dengan kandidat vaksin dan sediaan vaksin hasil inaktifasi ketika dilakukan preparasi gores pada media agar tidak ada yang tumbuh. Pengujian karakter kesamaan bakteri kandidat vaksin dilakukan dengan melihat sensitivitas terhadap beberapa jenis antibiotik yang sesuai dengan penelitian sebelumnya oleh Sugiani \& Lusiastuti (2011).

Gambar (1) menunjukkan kematian harian ikan tilapia yang di vaksin dan diuji tantang dengan bakteri yang sama (homolog). Perlakuan vaksin monovalen $A$. hydrophila maupun monovalen $S$. agalactiae terbukti hanya dapat memproteksi ikan dari uji tantang terhadap bakteri yang sama, tidak ada proteksi silang antar keduanya, hal ini terlihat dari kematian ikan yang tinggi setelah uji tantang dengan bakteri berbeda. Sementara, kematian ikan yang divaksin bivalen dengan sediaan sel utuh, ECP, crude supernatan, gabungan sel utuh dan ECP, maupun broth, relatif lebih tahan terhadap uji tantang dengan bakteri tunggal maupun gabungan. Kematian harian perlakuan vaksin bivalen berbeda nyata dengan perlakuan vaksin monovalen dan kedua perlakuan menunjukkan perbedaan yang nyata terhadap kontrol $(P<0,05)$. Jika dibandingkan antar perlakuan vaksin bivalen, maka perlakuan vaksin bivalen sediaan sel utuh dengan gabungan sel utuh + ECP tidak berbeda nyata ( $P>0,05)$, namun berbeda nyata dengan perlakuan vaksin bivalen sediaan ECP, crude supernatan, dan broth $(\mathrm{P}<0,05)$.

\section{Titer antibodi ikan}

Titer antibodi ikan Tilapia (Gambar 2, 3, dan 4) dengan perlakuan vaksin monovalen maupun bivalen menunjukkan perbedaan yang nyata dibanding dengan kontrol $(P<0,05)$. Hasil pengamatan antar perlakuan diperoleh data yang menunjukkan perlakuan vaksin bivalen sediaan sel utuh serta gabungan sel utuh + ECP memiliki titer antibodi yang lebih tinggi, baik pada uji tantang dengan bakteri tunggal maupun bakteri gabungan (ko-infeksi) pada nilai $\log 26$, dan 5 dibanding dengan bivalen (ECP, crude supernatan, dan broth). Hasil titer antibodi juga menunjukkan bahwa perlakuan vaksinasi monovalen ternyata lebih tinggi dalam membentuk respon imun dengan mencapai nilai $\log 27$ untuk monovalen $A$. hydrophila dan nilai log 25 untuk monovalen S. agalactiae jika dibandingkan dengan vaksin bivalen semua sediaan. Namun jika membandingkan proteksi vaksin bivalen terhadap uji tantang gabungan (ko-infeksi) menunjukkan nilai titer yang relatif lebih 

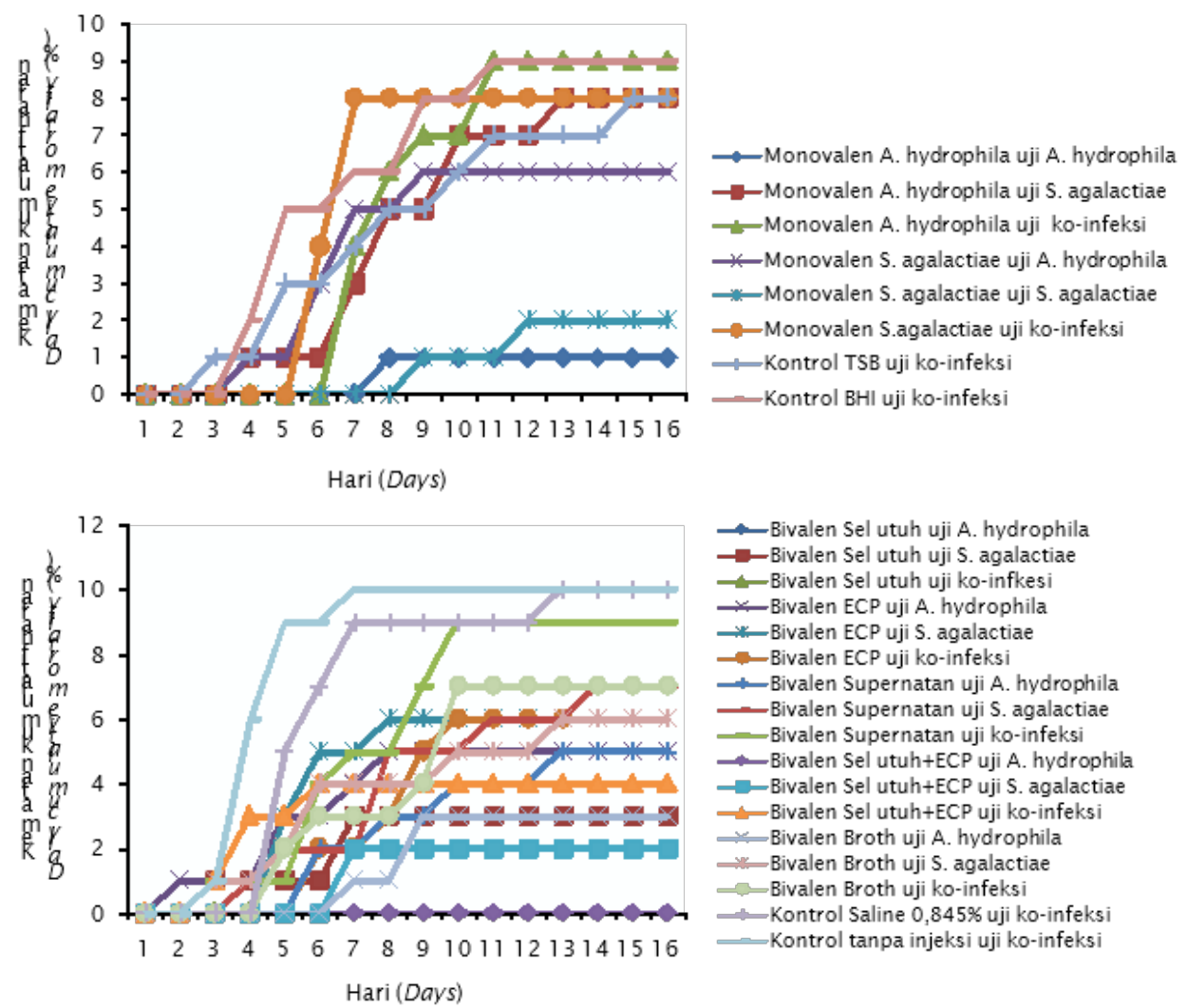

Gambar 1. Kematian harian ikan tilapia (O. niloticus) yang divaksin monovalen (A) dan bivalen (B) secara intraperitoneal dan diuji tantang selama 15 hari

Figure 1. Daily cumulative mortality of vaccinated fish tilapia (O. niloticus) using monovalent and bivalent vaccines by intraperitoneal injection and challange test for 15 days

rendah jika dibandingkan dengan uji tantang bakteri tunggal.

Rata-rata titer antibodi setiap perlakuan terjadi peningkatan pada minggu ke-2 pascavaksinasi. Perlakuan monovalen $A$. hydrophila, bivalen sel utuh, dan bivalen campuran sel utuh + ECP nilai puncak titer tertinggi diperoleh pada masa minggu ke-3 dan pada saat dilakukan uji tantang terlihat bahwa titer antibodi mengalami penurunan yang kemudian diikuti adanya peningkatan kembali pada masa pemulihan yaitu 2 minggu setelah uji tantang.

Vaksinasi aktif merupakan bentuk dari imunisasi aktif menggunakan stimulasi antigen untuk meningkatkan respon imun alami dan respon imun perolehan (adaptive) dengan menghasilkan spesifik respon imun humoral dan imunitas antara cell-mediated immunity terhadap patogen dan antigen spesifik (Skinner, 2009). Anbarasu et al. (1998) menemukan bahwa vaksin $A$. hydrophila yang diinaktifasi menggunakan neutral buffer formalin lebih baik dibanding dengan vaksin yang diinaktifasi dengan pemanasan, terutama ketika bakterin akan diaplikasikan melalui suntik dan disatukan dengan adjuvan. Akan tetapi, sonikasi sel untuk vaksin menghasilkan respon antibodi yang terbaik. Sonikasi akan memecah sel dan memungkinkan diperolehnya antigen somatik (lipopolisakarid bakteri). Tanpa memperhatikan apakah vaksin berbentuk sel utuh, freezethawed sel, atau sel hasil sonikasi, Thune \& Plumb (1982) menyatakan bahwa pemberian 


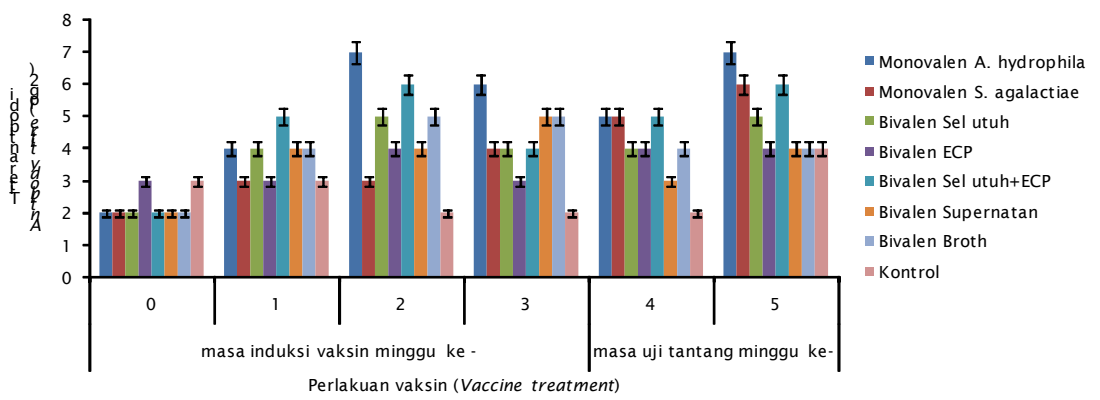

Gambar 2. Titer antibodi serum ikan tilapia (O. niliticus) pasca vaksinasi yang di tantang dengan bakterin A. hydrophila

Figure 2. Antibody titre of vaccinated tilapia (O. niliticus) challenging with bacterin A. hydrophila

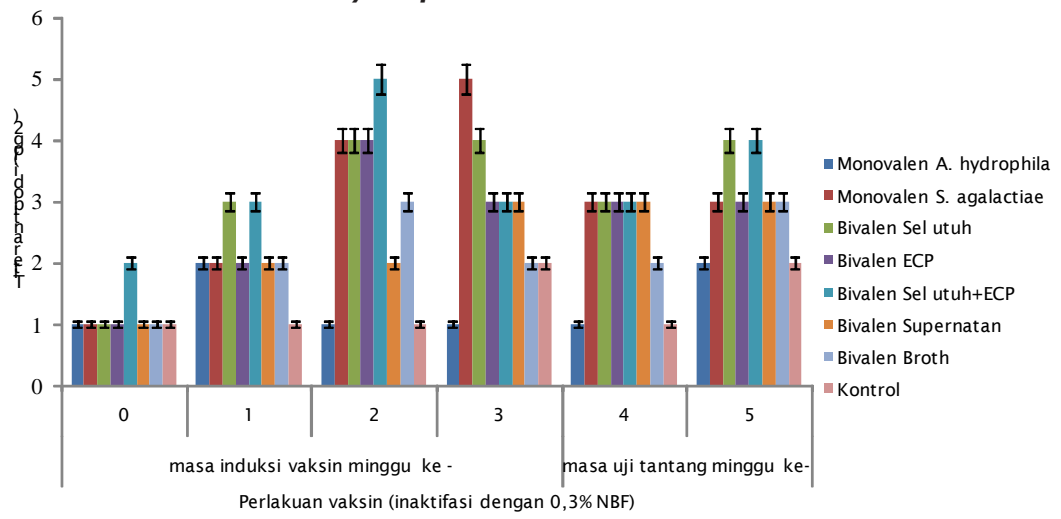

Gambar 3. Titer antibodi serum ikan tilapia (O. niliticus) pasca vaksinasi yang di tantang dengan bakterin S. agalactiae

Figure 3. Antibody titre of vaccinated tilapia (O. niliticus) challenging with bacterin S. agalactiae

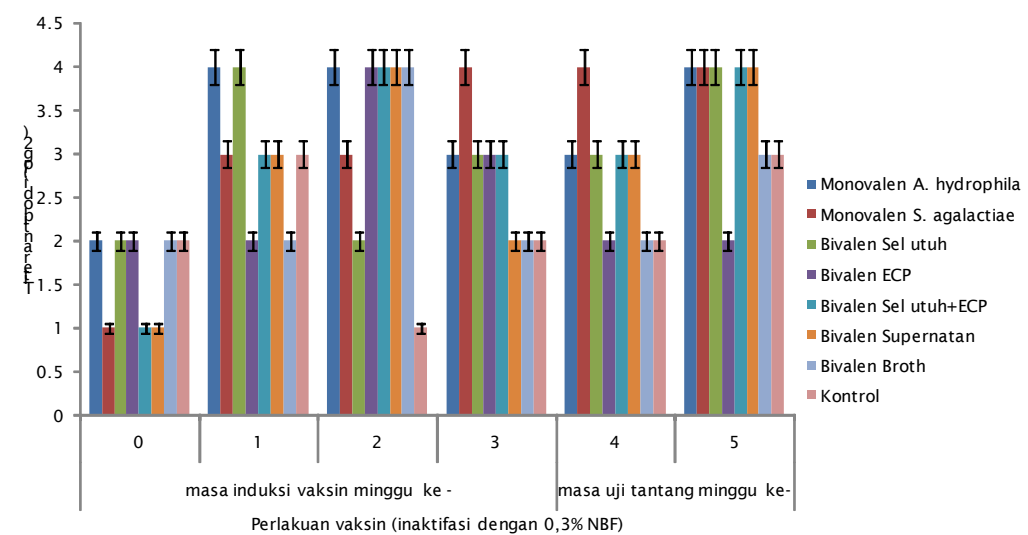

Gambar 4. Titer antibodi serum ikan tilapia (O. niliticus) pasca vaksinasi yang di tantang dengan ko-infeksi $A$. hydrophila dan S. agalactiae

Figure 4. Antibody titre of vaccinated tilapia (O. niliticus) challenging with co-infections $\boldsymbol{A}$. hydrophila and S. agalactiae 
vaksin A. hydrophila melalui suntik akan memberikan hasil yang lebih baik dalam membentuk respon humoral antibodi dibanding dengan pemberian vaksin melalui rendam atau semprot.

\section{Relative Percent Survival (RPS)}

Nilai RPS ikan tilapia pasca uji tantang menunjukkan hasil yang beragam (Tabel 2 ). Perlakuan vaksin monovalen berbeda nyata dengan perlakuan vaksin bivalen dan keduanya juga berbeda nyata dengan kontrol $(\mathrm{P}<0,05)$. Nilai RPS tertinggi $(100)$ didapat dari perlakuan vaksin bivalen sel utuh serta gabungan bivalen sel utuh dan ECP yang diuji tantang oleh bakteri tunggal $A$. hydrophila. Nilai RPS terkecil (2.7) didapat dari perlakuan vaksin bivalen crude supernatan yang diuji dengan bakteri ko-infeksi. Hasil pengamatan nilai RPS pada perlakuan uji tantang dengan bakteri ko-infeksi secara keseluruhan maka sediaan vaksin bivalen sel utuh serta gabungan bivalen sel utuh dan ECP yang memiliki nilai sama (56.7). Nilai RPS yang relatif rendah tersebut dari perlakuan vaksin bivalen terhadap ko-infeksi $A$. hydrophila dan $S$. agalactiae menunjukkan bahwa vaksin tersebut kurang protektif terhadap penyakit MAS dan Streptococcosis jika terjadi infeksi secara bersamaan. Namun apabila infeksi yang terjadi merupakan infeksi tunggal maka vaksin yang paling memberikan level proteksi tertinggi adalah vaksin bivalen gabungan sel utuh dan ECP.

Vaksin monovalen hanya dapat memproteksi dari serangan penyakit yang sama dan tidak dapat memproteksi dari infeksi silang maupun infeksi gabungan (ko-infeksi). Vaksin monovalen A. hydrophila hanya dapat memproteksi dari infeksi MAS, dan vaksin monovalen $S$. agalactiae hanya dapat memproteksi dari infeksi Streptococcosis.

Busch (1997) menjelaskan bahwa ada proteksi silang antar antigen (keberadaan satu antigen dapat memberikan proteksi terhadap antigen yang berbeda, bahkan terhadap antigen yang tidak memiliki keterkaitan), kompetisi antigenik (keberadaan satu antigen mempengaruhi atau menekan aktivitas antigen lain), dan terjadi imunodominansi antar antigen (setiap sub unit antigen determinan terlibat dalam proses pengikatan atau reaksi dengan antibodi) semua faktor tersebut dapat mempengaruhi spesifitas, aviditas, dan tingkat produksi antibodi spesifik (Abs).

Hampir semua vaksin memiliki potensi untuk dibuat dalam bentuk bivalen dan

Tabel 2. Tingkat RPS ikan tilapia (O. niloticus) yang di vaksin monovalen dan bivalen $A$. hydrophila dan S. agalactiae

Table 2. Relative Percent Survival/ RPS of vaccinated tilapia (O. niloticus) using monovalent and bivalent vaccines of $A$. hydrophila and S. agalactiae

\begin{tabular}{|c|c|c|c|}
\hline \multirow{2}{*}{$\begin{array}{l}\text { Perlakuan } \\
\text { Treatment }\end{array}$} & \multicolumn{3}{|c|}{$\begin{array}{l}\text { Relative percent survival (RPS) setelah diuji tantang } \\
\text { RPS after challenge }\end{array}$} \\
\hline & A. hydrophila & S. agalactiae & $\begin{array}{l}\text { Ko-infeksi (Co-infections) } \\
\text { A. hydrophila }+ \text { S. agalactiae }\end{array}$ \\
\hline Monovalen A. hydrophila & $89.2^{\mathrm{b}}$ & $17.2^{e}$ & $2.7^{\mathrm{d}}$ \\
\hline Monovalen S. agalactiae & $35.1^{\mathrm{e}}$ & $72.4^{b}$ & $13.5^{\mathrm{c}}$ \\
\hline Bivalen Sel utuh & $100^{\mathrm{a}}$ & $72.4^{b}$ & $56.7^{\mathrm{a}}$ \\
\hline Bivalen ECP & $45.9^{\mathrm{d}}$ & $31^{d}$ & $24.3^{\mathrm{b}}$ \\
\hline Bivalen Sel utuh+ECP & $100^{\mathrm{a}}$ & $86.2^{\mathrm{a}}$ & $56.7^{\mathrm{a}}$ \\
\hline Bivalen crude Supernatan & $45.9^{d}$ & $31^{d}$ & $2.7^{\mathrm{d}}$ \\
\hline Bivalen Brot $h$ & $67.6^{c}$ & $44.8^{c}$ & $24.3^{\mathrm{b}}$ \\
\hline
\end{tabular}

Angka yang diikuti oleh huruf yang sama pada kolom yang sama menunjukkan tidak berbeda nyata pada taraf uji $\mathrm{P}>0,05$

Figures followed by the same let ter in the same column indicat es no significant different in the level of test $P>0.05$ 
polivalen (vaksin dengan kandungan beberapa antigen; bakteri dan virus). Vaksin polivalen dapat melindungi individu ikan terhadap penyakit utama yang mungkin akan menyerang pada saat proses budidaya sampai ukuran siap panen, serta dapat menghindari kebutuhan akan vaksinasi ulang (Berg et al., 2006). Akan tetapi, vaksin polivalen terkendala oleh kemampuan ikan yang memiliki keterbatasan di dalam memberikan respon imun dan respon pengenalan multi antigen. Ikan memiliki kemampuan yang terbatas dalam kapasitas proteksi imunitas (rata-rata terbatas pada $5 \times 10^{5}$ antigen yang dapat dikenali vektor imun ikan sebagai antigen pada satu waktu), sehingga akan mempengaruhi efektifitas respon imun (Busch, 1997).

Kompleksitas dari sifat antigenik kelompok organisme yang beragam diperlukan strategi yang tepat dalam penggunaan vaksinasi, apakah dengan menggunakan vaksin polivalen, imunisasi menggunakan inaktifasi ekstraselular toksin (toxoid), atau vaksin yang berisi selular antigen dan toxoid. Vaksinasi dengan larutan antigen ekstraselular lebih efektif dalam memberikan perlindungan melawan serotipe yang heterolog dibandingkan dengan vaksin yang hanya terdiri atas satu jenis sel utuh dari antigen (Baba et al., 1988).

\section{KESIMPULAN}

1. Sediaan vaksin monovalen dan bivalen aman digunakan untuk pemberian secara injeksi intraperitoneal pada ikan tilapia $(O$. niloticus).

2. Sediaan vaksin bivalen (campuran sel utuh + ECP) memberikan level proteksi terbaik terhadap ikan tilapia berupa titer antibodi (log2 6) dan RPS (100) terhadap infeksi tunggal penyakit MAS maupun Streptococcosis.

3. Sediaan vaksin bivalen hanya dapat memproteksi terhadap ko-infeksi MAS dan Streptococcosis dengan nilai RPS (56.7).

4. Vaksin monovalen A. hydrophila hanya dapat memproteksi dari infeksi MAS, dan vaksin monovalen $S$. agalactiae hanya dapat memproteksi dari infeksi Streptococcosis.

\section{SARAN}

Perlu dilakukan penelitian lanjutan berupa uji lapang untuk melihat efektivitas dan keampuhan dari sediaan vaksin bivalen $A$. hydrophila $+S$. agalactiae terbaik ketika diaplikasikan secara langsung pada lingkungan budidaya ikan tilapia.

\section{DAFTAR ACUAN}

Aly, T.M. 1981. Studies on the effect of different adjuvant on the efficiency of FMD vaccine in farm animal.Ph. D. faculty of Vet. Med. Zagazig University.

Anbarasu, K., Thangakrishnan, K., Arun, B.V., \& Chandran, M.R. 1998. Assessment of immune response in freshwater catfish (Mystus vittatus Bloch) to different bacterins of Aeromonas hydrophila. Indian Journal of Experimental Biology, 36: 990995.

Anderson, D.P., Capstiek, P.B., \& Mowat, G.N. 1970. In vitro method for safety of fmd. $J$. hyg Gamd, 68: 159-1 72.

Baba, T., Imamura, J., Izawa, K., \& Ikeda, K. 1988. Immune protection in carp, Cyprinus carpio L., after immunization with Aeromonas hydrophila crude lipopolysaccharide. Journal of Fish Diseases, 11: 237-244.

Berg, A, Rodseth, O.M., Tangeras, A., \& Hansen, T. 2006. Time of vaccination influences development of adhesions, growth and spinal deformities in Atlantic salmon, Salmo salar. Diseases of Aquatic Organisms 2006, 69: 239-48.

Busch, R.A. 1997. Polyvalent vaccines in fish: the interactive effects of multiple antigens. In: Gudding R., Lillehaug, P.J., Midtlyng, P.J., Brown F. (eds.). Fish Vaccinology; Developments in Biological Standardization, Basel, Switzerland: Karger, 90: 245-56.

Ellis, A.E. 1988. General principles of fish vaccination. In: Ellis A-E (ed.) Fish vaccination. Academic Press, London, p. 1-19.

Evans, J.J., Klesius, P.H., \& Shoemaker, C.A. 2004. Eficacy of Streptococcus agalactiae (group B) vaccine in Tilapia (Oreochromus niloticus) by intraperitoneal and bath immersion administration. Vaccine, 22: 3,7693,773 .

Hardi, E.H., Sukenda, Harris, E., \& Lusiastuti, A.M. 2010. Efikasi sel utuh dan produk ekstraselular bakteri Streptococcus agalactiae tipe b-haemolitik dan nonhaemolitik sebagai vaksin untuk pencegahan Streptococcosis pada ikan tilapia (Oreochromis niloticus). Simposium Nasional Bioteknologi Akuakultur III. Bogor. 
Ismail NEDA, Atta, N.S., \& Aziz, A.E. 2010 . Oral Vaccination of Nile Tilapia (Orechromis niloticus) Against Motile Aeromonas Septicaemia. Nature and Science.

Klesius, P.H., Shoemaker, C.A., \& Evans, J.J. 1999. Efficacy of an inactivated Streptococcus iniae vaccine in Tilapia (Oreochromis niloticus). Eur. Assoc. Fish Pathol., 19(1): 13.

Li, A., Yang, A.L.W., Hu, J., Wang, W., Cai, T., \& Wang, J. 2006. Optimization by orthogonal array design and humoral immunity of bivalent vaccine against Aeromonas hydrophila and Vibrio fluvialis infection in crucian carp (Carassius auratus L.). Aquaculture Research, 37: 813-820.

Lusiastuti, A.M., Purwaningsih, U., \& Hadie, W. 2010. Vaksin Streptococcus agalactiae: I. Kajian Inaktifasi Sel Utuh (Whole cell) Melalui Formalin (Formalinkilled) Untuk Pencegahan Penyakit Streptococcosis pada Ikan Tilapia, Oreochromis niloticus. Forum Inovasi Teknologi Akuakultur.

Ni, X.D., Wang, N., Liu, Y.J., \& Lu, C.P. 2010. Immunoproteomics of extracellular proteins of the Aeromonas hydrophila Chinavaccine strainj-1 reveal a highly immunoreactive outermembrane protein. FEMS Immunol Med Microbiol., 58: 363-373.

Osman, K.M., Mohamed, L.A., Rahman, E.H.A., \& Soliman, W.S. 2009. Trials for Vaccination of Tilapia Fish Against Aeromonas and Pseudomonas Infections Using Monovalen, Bivalent and Polyvalent Vaccines. World Journal of Fish and Marine Sciences 1 (4): 297-304.

Pasnik, D.J., Evans, J.J., Panangala, V.S., Klesius, P.H., Shelby, R.A., \& Shoemaker, C.A. 2005. Antigenicity of Streptococcus agalactiae extracellular products and vaccine efficacy. Journal of Fish Diseases, 28: 205-212.

Rodrigues, A.P., Hirsch, D., Figueiredo, H.C.P., Logato, P.V.R., \& Moraes, A.M. 2006. Production and characterization of alginate microparticles incorporating Aeromonas hydrophila design for fish oral vaccination. Process Biochemistry, 41 : 638-643.
Shoemaker, C.A., LaFrentz, B.R., Klesius, P.H., \& Evans, J.J. 2010 . Protection against heterologous Streptococcus iniae isolates using a modified bacterin vaccine in Nile tilapia, Oreochromis niloticus (L.). Journal of Fish Diseases, 33: 537-544.

Silva, B.C., Martins , M.L., Jatoba, A., Neto, C.C.B., Vieira, F.N., Pereira, G.V., Jeronimo, G.T., Seiffert, W.Q., \& Mourino, J.L. 2009. Hematological and immunological responses of Nile Tilapia after polyvalent vaccine administration by different routes 1 . Pesq. Vet. Bras., 29(11): 874-880.

Skinner, L.A. 2009. The Physiological and Immunological effects of vaccination on fish health, werfare, and performance. The University of British Columbia, 139 pp.

Sugiani, D., Komarudin, O., Wadjdi, E.F., Mikadarullah, \& Wibawa, B.M. 2010. Efektifitas aplikasi rendaman ulang sediaan produk vaksin Hydrovac. Seminar Nasional Ikan VI \& Kongres Masyarakat Ikhtiologi Indonesia III. Lembaga IImu Pengetahuan Indonesia (LIPI) Cibinong, 0809 Juni 2010.

Sugiani, D. \& Lusiastuti, A.M. 2011 . Kerentanan Ikan Tilapia (Oreochromis niloticus) terhadap serangan ko-infeksi Streptococcosis dan MAS. SEMNASKAN VIII Universitas Gajah Mada, Yogyakarta, 16 Juli 2011.

Swain, P., Behura, A., Dash, S., \& Nayak, S.K. 2007. Serum antibody response of Indian major carp, Labeo rohita to three species of pathogenic bacteria; Aeromonas hydrophila, Edwardsiella tarda and Pseudomonas fluorescens. Veterinary Immunology and Immunopathology, 117: 137141.

Thune, R.L. \& Plumb, J.A. 1982. Effect of delivery method and antigen preparation on the production of antibodies against Aeromonas hydrophila in channel catfish. Progressive Fish-Culturist, 44: 53-54.

Toranzo, A.E., Romalde, J.L., Magariños, B., \& Barja, J.L. 2009. Present and future of aquaculture vaccines against fish bacterial diseases. The use of veterinary drugs and vaccines in Mediterranean aquaculture. Options Méditerranéennes, A, 86: 155-176. 